This is the pre-peer reviewed version of the following article: Heeks, R \& Stanforth, C., Understanding development project implementation: an actor-network perspective, Public Administration and Development, 34(1), 14-31, 2014, which has been published in final form at:

http://onlinelibrary.wiley.com/doi/10.1002/pad.1671/abstract

\title{
Understanding Development Project Implementation: An Actor-Network Perspective
}

Richard Heeks ${ }^{1}$ and Carolyne Stanforth

IDPM, Arthur Lewis Building

University of Manchester, M13 9PL, UK

Tel: +44-161-275-2870

Email: richard.heeks@manchester.ac.uk

\footnotetext{
${ }^{1}$ Corresponding author
} 


\title{
Understanding Development Project Implementation: An Actor-Network Perspective
}

\author{
Abstract \\ Development projects are central to international development, yet the actual practice \\ of their implementation appears under-researched. In particular, we know little about \\ how practice affects project performance, and about how politics is enacted within \\ development projects. This paper investigates these knowledge gaps through analysis \\ using actor-network theory (ANT) of a donor-funded reform project in the Sri Lankan \\ public sector. \\ By analysing the mobilisation, interaction and disintegration of the local and global \\ actor-networks that typically surround such development projects, the paper explains \\ the project's trajectory. These actions must, in turn, be understood in relation to \\ network actor power: not through a static conception of 'power over' others but \\ through the dynamic enacted concept of 'power to'. The paper concludes by reflecting \\ on the value and application of ANT's local/global networks component in analysing \\ development projects, and in providing insights for development project practice.
}

Keywords: development management; actor-network theory; project implementation; public sector reform; Sri Lanka

\section{Introduction}

Development projects are central to international development. They represent the mechanisms by which development goals become development impacts, and we may define them in that way, as organised means seeking to achieve specific development impacts. Despite this importance, development projects as a generic entity appear under-researched (Struyk, 2007). In particular, the nature of practice within development projects seems to have been the subject of limited description and limited analysis in recent years. 
One posited reason has been the relative decline within development studies of development management (McCourt and Gulrajani, 2010). That decline has been mirrored and, in part, caused by the rise of the 'governance model' which has argued the failure of managerialism in development, and prompted a shift in focus to states and institution building; hence a shift from management and organisations to institutions and politics.

If the study of implementation practice within development projects is to be revived within this context, it will require two things. First, a deeper, more ethnographic understanding of project practice including an understanding of how that practice influences project performance (Lewis et al., 2003; Mosse and Lewis, 2006). In addition, 'a new sensitivity to politics and a better understanding of its influence on management', formed around analysing 'the interaction of power, including in the practice of development agencies' (McCourt and Gulrajani, 2010: 88). This current paper investigates how such a revival might be enacted, using the lens of actornetwork theory (ANT). As Law (1992: 387) notes, 'actor-network theory is all about power' and at the same time it is all about the mechanics of practice, typically relating that to the trajectory of a particular scheme or innovation. It therefore seems to be a good candidate for test.

In the remainder of the paper, we will first review some of the arguable lacunae in the study of development projects, focusing on these issues of practice, performance, actors and politics. The paper will then outline one component of actor-network theory that seems particularly relevant to the study of international development projects. The paper then applies that component - the notion of local/global networks - to one such project, part of the public sector reform process in Sri Lanka. Finally conclusions are drawn about the insights offered into the analysis of development projects, into actor-network theory, and into lessons for practice. 


\section{Literature Review}

Many of those who work in development spend much of their time on project management and implementation, with projects being the main mechanism by which development assistance is delivered (Diallo and Thuillier, 2005). Yet development studies as a discipline appears itself to have spent relatively little time recently analysing this activity (Bebbington et al., 2007; Struyk, 2007). As one exemplar, a review of published research in seven leading development studies journals ${ }^{2}$ from 2000 to 2011 reveals less than five papers investigating the specific practice of development project implementation and management, and none that would readily be identified as drawing from development management: that fraction of development studies which seeks to apply management concepts to development.

In part, the lack of analysis of project practice arises because of the connection with, and relative decline of, development management within development studies (McCourt and Gulrajani, 2010). Yet development management has had its own weaknesses in accounting for project practice. It has tended to take a relatively linear and rationalist perspective on practice (Mowles et al., 2008). But this view is 'abstract and idealised' (ibid.: 809). It bears little relation to the realities of development as 'an essentially contested, political and messy process' (Leach et al., 2008: 735) in which development project staff are well aware of the role of politics (Abouassi, 2010).

From this we can identify two lacunae in the study of development projects. First has been a relative lack of insight into practice and performance: the real rich detail of what occurs during the implementation of a project, and how that relates to the delivery or otherwise of project outputs. Analyses of project performance tend to settle on relatively quantitative and cross-sectional categorisations of 'success' or 'failure' (Ika and Lytvynov, 2011; Khang and Moe, 2008). Those performance outcomes have typically been ascribed to particular factors within the project or its

\footnotetext{
${ }^{2}$ World Development; Journal of Development Studies; Development and Change; Development Policy Review; European Journal of Development Research; Studies in Comparative International Development; Third World Quarterly. We excluded Public Administration and Development from the analysis because, of course, this topic is its core focus.
} 
environment, rather than associated with the dynamics and mechanics of project practice (Gow and Morss, 1988; Ika et al., 2009).

Second, there has been relatively little consideration of the political within development projects (Rossi, 2004). These twin absences of insight arise through the derivation of development management from foundations of management thought, particularly in public administration. Notions of linearity and rationalism derive both from early North American visions of Taylorist machine bureaucracy, and early European visions of Weberian bureaucracy, that focus on the structural and the factoral and that exclude a role for the informal and the political (Bogason and Toonen, 1998). Even when revised as in Simonian notions of goal orientation and systems thinking, objective assumptions about cause and effect were dominant and politics was an aberration, a 'disturbance' that was to be squeezed out and marginalised by management techniques.

Issues of practice and performance have been explored within the literature on process approaches to development projects (e.g. Bond and Hulme, 1999; Toner and Franks, 2006). But, perhaps influenced by the dominant rationality of management thought, they have tended to fall back on a factor-analytical and prescriptive approach, which still treats politics as a 'critical barrier' to good management practice (ibid.: 90).

Development management's limited encompassing of politics is not just problematic because of the mismatch to politicised reality in development projects. It is also problematic because of the shifting trends in development thought, with governance emerging as a force shaping conceptualisation (and implementation) of development projects (Santiso, 2001; Williams and Young, 1994). This has led to a growing interest in politics within development, and growing value for those disciplines and theories which were able to place politics centre stage: 'Thus donor agencies have ... looked to political scientists and economics rather than development management specialists' (McCourt and Gulrajani, 2010: 83).

Unfortunately, governance models have their own shortcomings. They have been part of a broader domination of development by structural conceptualisations (van der Ploeg, 2006). This has left little room for an interest in or understanding of 
development practice, and it has 'dehumanised' accounts of development projects, with individual actors and their agency struggling to appear (Mosse and Lewis, 2006).

The sense we have, then, is of a jigsaw with a missing piece. Development management, including the process approach literature, has had strengths in reflecting aspects of development practice, such as agency and 'the role of individual development actors' (McCourt and Gulrajani, 2010: 84), but it has made limited progress in linking these to project performance and it has approached projects in a rather idealised and de-politicised manner that does not reflect project realities. Political science and political economics have, of course, been good at addressing politics in development at a certain level, but poor at recognising and analysing the practice of development projects and the agency of individual actors; and also poor at helping us understand project trajectories as a result.

To fill the gap, we would wish for an approach that focuses on actors and practice and links these to project performance but which does so in a way that reflects the rather messy and politicised realities of development projects. What does actor-network theory have to offer? That is the question we will seek to answer in the remainder of this paper.

Actor-network theory can be seen as one aspect of a broader turn in development towards analysis of practice, of actors, of agency (Long and Long, 1992; Sumner and Tribe, 2008). Still, despite this compatibility with larger tides and despite being more than two decades old, ANT has so far been very little applied to analysis of development projects. Review of the same seven development journals plus Public Administration and Development, again during 2000 to 2011, found only two papers Mahanty (2002) and Veldwisch et al. (2009) - that allude to actor-network theory when analysing development projects but neither uses it as the central organising conceptualisation.

A possible reason for this lack of use could be the perceived complexity and diversity of ANT; and its migration from a relatively bounded set of new ideas about how science works to a grand 'alternative social theory' (Latour, 2005: ix). Navigating these waters is not easy, so our wish for this paper was to identify and use a fairly 
clear and well-defined sub-set of ANT ideas that would have particular relevance to development projects.

One defining feature of many such projects is that they represent an intersection of the local and the global, bringing together a network of multiple actors working at different scales (Bebbington, 2007; Struyk, 2007). On that basis, it therefore seemed appropriate to make use of the local/global networks approach offered by Law and Callon $(1988,1992)$ in their analysis of an individual project. Law and Callon's network analysis model charts the initiation, development and eventual demise of the TSR 2 military aircraft project in the UK during the 1950s and 1960s. Their premise is that a project can be seen as a function of the interaction of heterogeneous elements in two networks.

One, a global network, is that set of relations 'that is built up, deliberately or otherwise, and that generates a space, a period of time, and a set of resources in which innovation takes place.' (Law and Callon, 1992: 21). This can be seen as the 'outside' of the project; that which enables it to take place with the resources provided including money, expertise and political support. In the TSR2 case, it consisted of actors such as the Ministry of Defence and various Armed Forces plus influential politicians, civil society movements, and new technologies.

The second is a local network: that set of relations 'necessary to the successful production of any working device.' (ibid.: 22). This can be seen as the 'inside' of the project; the relation of actors which actually implements the project. In the TSR2 case, these included private sector contractors, public sector officers, technical artefacts, and documents.

The changing strength of each network can be plotted on a two-dimensional graph where the $\mathrm{x}$ axis measures the degree of mobilisation of local actors and the $\mathrm{y}$ axis the degree of attachment of global actors (see Figure 1). 
Figure 1. Mobilisation of local and global networks (Law and Callon, 1992)

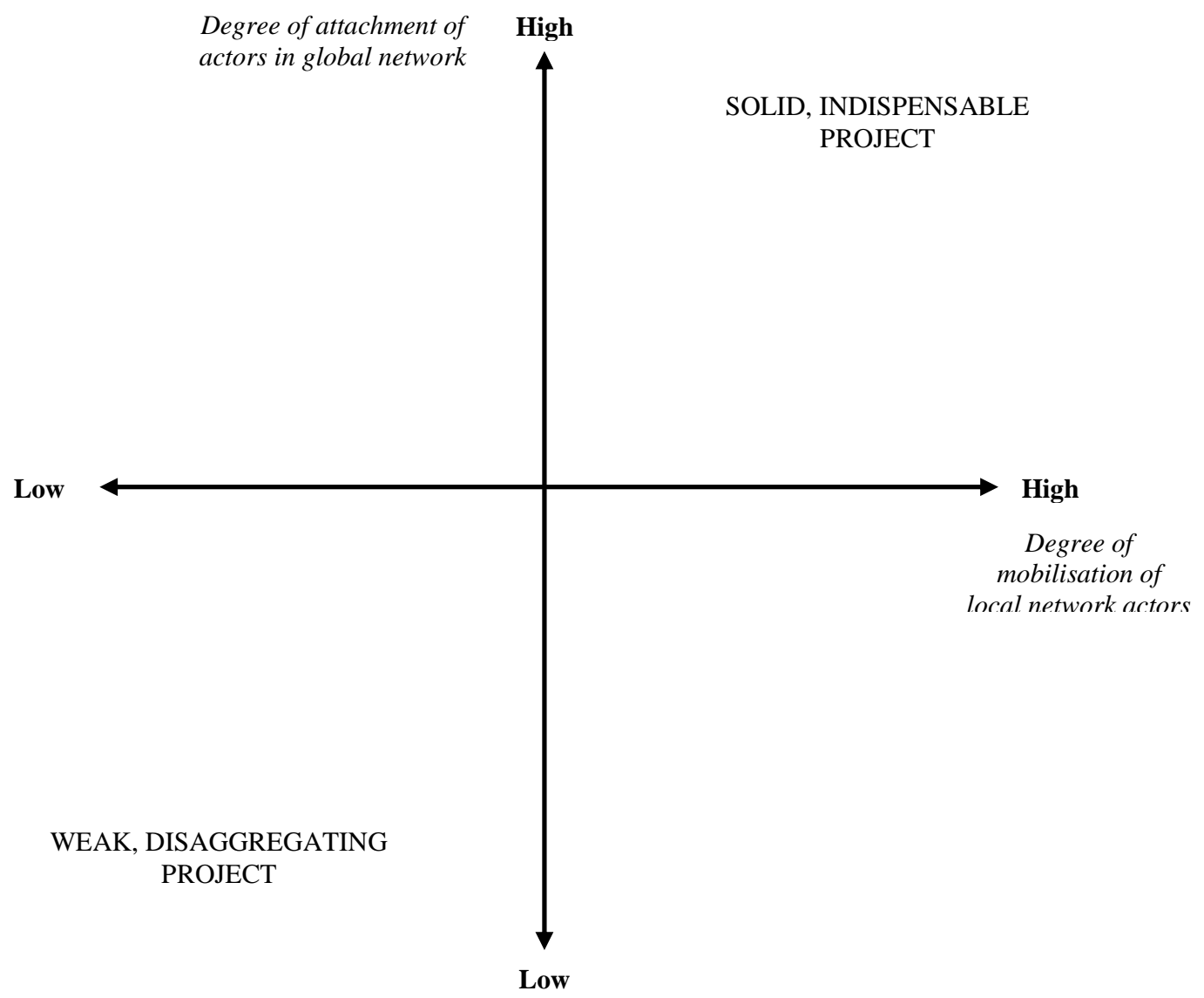

In the case of the TSR2 project, it began in the top-right quadrant with a global network that was able to 'for a time provide resources of various kinds in the expectation of an ultimate return.' (ibid.: 46), and a local network able to use 'the resources provided by the global network to ... offer a material, economic, cultural, or symbolic return to actors lodged in the global network.' (ibid.: 46). Yet over time, neither the global nor the local networks could be successfully maintained, and the mapping ended in the bottom-left quadrant with the TSR2 aircraft being cancelled.

The analysis suggests that the necessary maintenance of the networks was hampered by the lack of a clear obligatory point of passage; that is, a single locus controlling transactions between the networks. There was 'seepage' between the global and local networks that undermined each: actors in the global network were able to interfere with the structure and shape of the local network and local network actors were able to consult directly and independently with individual global network actors. The result 
was that the local network did not have the necessary independence of action required to achieve the goals set by the global network.

But if the nature and relations of these two networks help explain the performance of a project how, in turn, can we understand those networks? We can understand them better by seeking to understand power from an ANT perspective. To do that, we follow Law (1986) in drawing on Foucault's ideas. Foucault explains what power is not. It is not a group of institutions and mechanisms that ensure the subservience of the population of a given state or a general system of domination exerted by one group over another. The possibility of power is not conditional upon and should not be sought 'in the primary existence of a single point, in a unique source of sovereignty from which secondary and descendent forms would emanate' (Foucault, 1984: 93). Power is not in the possession of certain people or institutions who wield it over others, dominating and constraining them: rather it is relational and productive (since without power, nothing is achieved).

Understanding power relationships in ANT thus means describing the way in which actors are defined, associated and obliged to remain faithful to their alliances. In ANT, translation is the mechanism by which the networks progressively take form, resulting in a situation where certain entities control others. The translation model of power (Callon, 1986) presents a successful command as resulting from the actions of a chain of agents, each of whom translates or shapes it according to their own objectives. Those who are powerful are not those who hold power in principle but those who practically define or redefine what holds everyone together.

This shift from principle to practice allows the vague notion of power to be treated not as a cause of people's behaviour but as a consequence of an intense activity of enrolling, convincing and enlisting. This 'power to' enact is in contrast to the dictionary definition of power, which concentrates almost entirely on authority and its various permutations, with the ability to exercise 'power over' being central (Pfeffer, 1992). For Latour (1986), the problem of power is encapsulated in the following paradox: when you simply have power - in potentia - nothing happens and you are powerless; when you exert power - in actu - others are performing the action and not you. Temporarily enrolled into networks, agents translate commands in accordance 
with their own ends, obeying for many different reasons and in aggregate giving 'an illusion of power' (ibid.: 268) to those they obey. An understanding of power will thus not help us understand the causes of local and global network formation, but will allow us to better understand that formation.

\section{Methodology and Case Overview}

\section{Methodology}

A key tenet of research based around actor-network theory is that it should be able to tell the story of a particular case in rich detail and over a period of time. We felt this would most readily be achieved through longitudinal participant observation, and thus selected a financial reform project in the Sri Lankan public sector in which author *** participated between 2000 and 2003 as a member of an international consultant team.

This project was also selected because it was seen as typical of some development projects: with an international donor agency as part of the global resource-providing network $^{3}$, falling under the public sector reform and good governance agendas that have partly shaped development in recent years, and involving both public and private sectors in planning and implementation. The case study has been a methodology of choice for ANT-based research (e.g. Callon, 1986; Law and Callon, 1992), and was seen as appropriate to our specific interests, which - rather than seeking generalisation - sought to identify the particular insights an ANT frame could bring to understanding development project implementation. Studying a case longitudinally does provide the potential for analytic generalisation and external validity (Yin, 2003).

\footnotetext{
${ }^{3}$ 'Global' and 'local' in ANT terms do not refer to geographical location or scale, but role and position vis-à-vis a particular case project. For international development projects, network members could be thought of as global or local in those other senses, and there might be a mapping e.g. international donor agencies are global organisations and are likely to be members of a project's global network. But, as will be seen later, the international accounting firm is also a global organisation but its staff members belonged just to the local network on this project.
} 
We sought to address internal validity by asking the same questions of different sources of evidence during the fieldwork; a triangulation of 'multiple perceptions' of the same phenomena that is typical within a case study methodology (Stake, 2003: 148). The initial foundation for this was the author ***'s project diary, kept during her three-year direct participation in process improvement and capacity-building in Sri Lanka's Ministry of Finance, supplemented by observational data and personal documents such as email correspondence.

This participant observation data was triangulated with three other sources. A series of interviews with key project stakeholders was undertaken between 2003 and 2005 during two periods of fieldwork. In all, twenty-four semi-structured interviews were held, involving senior officials responsible for project leadership and facilitation, midlevel officials responsible for project implementation, and representatives from local consulting, international consulting and donor agencies. Further documentary evidence was gathered and analysed. This included the formal internal documents such as strategy documents and progress reports - from the financial reform project, and reports from local newspaper archives. The final source of evidence came from physical artefacts. The attributes of the information technologies associated with the project (such as accounting and budget systems, and local area networks) were examined in detail, alongside a review of the physical environment in which the project was implemented.

Computer-assisted routines within the software package NVIVO were used to categorise the narrative text elements of these sources in order to identify salient concepts and themes. In order to structure the analysis, Law and Callon's framework was utilised meaning that data categories were shaped and filtered on the basis of key events and identified network actor relations and actions. The essential underlying logic was the match between identified data points and theoretical constructs. Such logic models are conceptually a form of pattern matching (Wholey, 1979) but are unique in that sequential stages are identified whereby a chain of events takes place over time. 


\section{Development Project History}

The focal project was the 'Public Expenditure Management Systems' (PEMS) project launched by the Asian Development Bank (ADB) in collaboration with the Sri Lankan Ministry of Finance (MoF) in 1999, and ending in 2003. Alongside these two members of the global network for the project were a series of other human actors, summarised in Table 1 who emerge to a greater or lesser extent in the case history related below.

\section{Table 1. Classification by Function of the Key Human Stakeholder Groups ${ }^{4}$}

\begin{tabular}{|c|c|c|c|c|}
\hline Group & Organisation & Department & $\begin{array}{c}\text { Project } \\
\text { Role }\end{array}$ & Network \\
\hline $\begin{array}{l}\text { Government } \\
\text { of Sri Lanka }\end{array}$ & $\begin{array}{l}\text { Ministry of Finance } \\
\text { Other Ministries }\end{array}$ & $\begin{array}{l}\text { Leadership } \\
\text { State Accounts Department } \\
\text { National Budget } \\
\text { Department } \\
\text { National Planning } \\
\text { Department } \\
\text { Other Departments } \\
\text { Line Ministries } \\
\text { Prime Minister's Office }\end{array}$ & $\begin{array}{c}\text { Design/Use } \\
\text { Design/Use } \\
\text { Design/Use } \\
\text { Design/Use } \\
\text { (Use) } \\
\text { Use } \\
\text { (Use) }\end{array}$ & $\begin{array}{l}\text { Global } \\
\text { Local } \\
\text { Local } \\
\text { Local } \\
\text { (Local) } \\
\text { Local } \\
\text { (Global) }\end{array}$ \\
\hline $\begin{array}{l}\text { International } \\
\text { Financing } \\
\text { Institutions }\end{array}$ & $\begin{array}{l}\text { Asian Development } \\
\text { Bank }\end{array}$ & $\begin{array}{l}\text { Head Office } \\
\text { National Office }\end{array}$ & $\begin{array}{l}\text { Design } \\
\text { Design }\end{array}$ & $\begin{array}{l}\text { Global } \\
\text { Global }\end{array}$ \\
\hline Suppliers & $\begin{array}{l}\text { International } \\
\text { Accounting Firm }\end{array}$ & $\begin{array}{l}\text { National Practice } \\
\text { International Practice }\end{array}$ & $\begin{array}{l}\text { Design } \\
\text { Design }\end{array}$ & $\begin{array}{l}\text { Local } \\
\text { Local }\end{array}$ \\
\hline Civil Society & $\begin{array}{l}\text { Institute of Public } \\
\text { Finance and } \\
\text { Development } \\
\text { Accountancy } \\
\text { Media }\end{array}$ & & (Use) & (Global) \\
\hline
\end{tabular}

The central puzzle of the case history is how an initial design for reform in 1999 came to be rejected but then emerged in a new way as the basis for the project. To understand that, in part, we must recognise that any development project will have a 'pre-history'.

\footnotetext{
${ }^{4}$ Classifications in brackets represent actors with more minor roles in this narrative.
} 
There is some arbitrariness in selecting the starting point for any pre-history but we begin ours in 1996 when the ADB provided funds to Sri Lanka for a new governmentwide accounts system. This system - called CIGAS: Computerised Integrated Government Accounts System - was designed by an in-house team from the Ministry of Finance's State Accounts Department. A user training programme was undertaken and the CIGAS software was implemented in more than 2,000 government offices throughout the country. CIGAS collected financial data from all these offices and fed it into the central Treasury Accounting System (TAS) that automated the production of monthly and quarterly national accounting statements. The CIGAS/TAS project was then Sri Lanka's largest computerisation programme. It 'raised significantly the skill levels of civil servants and, by working towards the control, accountability and transparency of government finances, created the enabling environment in which an effective public expenditure information system can be built' (PricewaterhouseCoopers, 2000: 20).

As a next step, the Asian Development Bank then proposed to the Ministry of Finance that it should move to modernise its whole system of public expenditure management. This became the basis for the PEMS project, which was formalised through an agreement signed between the ADB and two senior officials - the Secretary Treasury and the Director General of the External Resources Department - in 1999. Its centrepiece is creation of 'a new computerised system [that] will integrate all key financial management functions into a cohesive system on a common database' (ADB, 1999: 5); those functions covering all aspects of budgeting, accounting, treasury and debt management and involving five departments in the Ministry.

PEMS presents an ambitious, technology-centred vision for change; and one that is seen as paving the way for wider reform: 'The proposed assistance to these departments will enhance financial accountability, help reduce corruption, provide a strong foundation for eventual comprehensive administrative reform, and improve public resource efficiency.' (ibid.). As a first step, a team of consultants is hired from an international accounting firm and a Steering Committee constituted through which all major decisions will pass. It is to be chaired by the Secretary Treasury and to draw representation from other actor groups. 
During 2000, the consultants meet with various stakeholders within the Ministry and produce a strategy document. Based on their conception of international best practice, the consultants recommend that Sri Lanka moves quickly to start-of-the-art in PEMS, with brand new, integrated systems across the range of expenditure functions that will cost US\$40m to install over a three-year period, and US\$2m per year in recurrent costs.

However, once this radical tabula rasa strategy is circulated for approval, it becomes clear that most of those on the government side feel little or no ownership. The Ministry leadership complains to the ADB. Advised by the IT Unit of the State Accounts Department (owner of the existing CIGAS/TAS system), they cite particularly what they see as the high recurrent costs of this strategy (costs that the Ministry, not the ADB, will have to bear). And they request an urgent review of the project.

A senior ADB delegation is despatched to Sri Lanka. They find not only discontent over the design, but other issues: distracted by the pressures of national elections, senior officials have not been convening the project Steering Committee. The five departmental task forces intended to help implement the project have never been formed. Counterpart funding from the Ministry - intended to provide salary incentives for staff to join those task forces - has instead been spent on relocating the consultant's project office from the Ministry's old colonial-era building to a modern tower block that overlooks it. State Accounts Department staff complain about the technology-led approach adopted by the consultants with one SAD manager commenting:

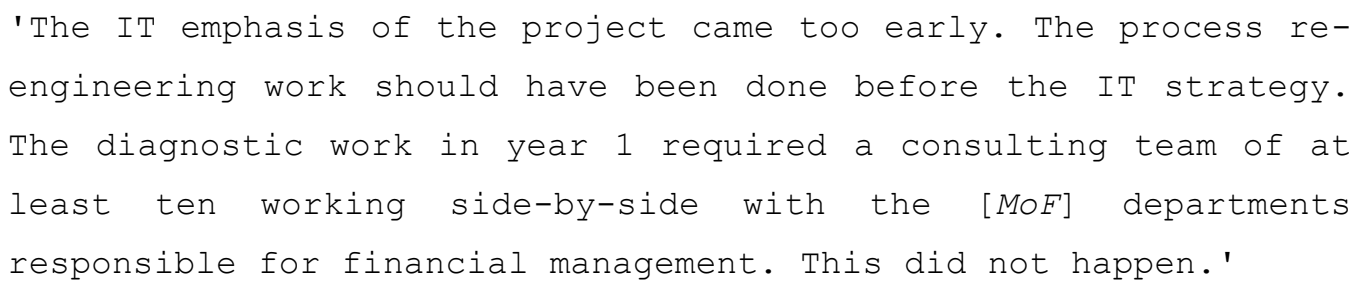

They also complain to the ADB that this 'big bang' type of approach failed to recognise 'the accomplishments of CIGAS and other systems developed by the MoF' (ADB, 2001: 10). 
Face-to-face, the international consultants are reassured, with the ADB delegation leader telling them, 'The review is not an attack on you; it is to assist in ensuring you can meet your contractual responsibilities'. In practice, though, the ADB abandons the direction of, and approach to, the project that has been taken by the consultants. Following an extensive series of meetings over a two-week period, a new LogFrame is produced for the project which aims for a strategy of improving the 'functioning basics' by integrating and enhancing the systems already in the Ministry rather than starting from scratch with new systems. The five departments involved in the initial project design are reduced to three: the State Accounts Department, the National Budget Department (NBD), and the National Planning Department.

There are personnel changes with the Asian Development Bank officer-in-charge being replaced. The Ministry appoints a full-time project director from within the NBD who will act as the single point of contact for the project. Consulting responsibility is switched from the international to the national office of the accounting firm, with a private warning that their staff must relocate back into the MoF building and abandon the previous strategy or else the contract will be directed elsewhere. Elections also bring in a new team of senior officials at the Ministry, including a Permanent Secretary who is a close colleague of the Prime Minister and who shares the latter's vision for a public sector transformed through use of digital technology. The ADB makes clear that MoF senior staff must actively engage with and support the new project design or else funding will be cancelled.

Implementation of the new project during 2002 and 2003 focuses on three main deliverables. Procedural changes are introduced that can eventually lead the Ministry to adopt international public sector accounting standards, a move which triggers training and other support from Sri Lanka's Institute of Public Finance and Development Accountancy (IPFDA: a professional body to which many MoF officers belong). A local area network is set up within the Ministry that makes it much easier to share financial data and send messages, with one NBD manager commenting that it 'has been a key deliverable that is already changing behaviour with a growing amount of intra- and inter-departmental communication'. 
Thirdly, the consulting team works with in-house staff to add a new software 'layer' on top of the existing systems which can integrate and aggregate the data held in those systems. Within the State Accounts Department, this allows a unified national accounting report to be produced on time for the first time which, unlike previous reports, receives a supportive rather than qualified opinion from the Auditor General (Chandrasena, 2003). In the National Budget Department, an integrated budget system (IBS) is designed which interfaces with the existing CIGAS/TAS accounting systems. Budget preparation and execution information thus become available to the $\mathrm{MoF}$ and line ministry users from one single source. Liking what they see during the prototyping phase, the National Planning Department asks for their own capital projects module to be included within the IBS.

A public launch of the web-enabled IBS is timed to coincide with Sri Lanka's first National e-Government Conference and a conference on international accounting standards organised by the Institute of Public Finance and Development Accountancy. At the former, the MoF's Permanent Secretary boasts the IBS to be the country's first example of interactive e-government and receives extensive media coverage as a result (Financial Times, 2003). The latter marks the end of PEMS project and is addressed by key individuals including the Minister of Finance, the Secretary Treasury, and the Auditor General; all of whom in some way validate and add legitimacy to the achievements of the project. They also look forward to the next stage of financial reform; reflecting the start of another story that would be our case project's 'post-history'. 


\section{Development Project Analysis}

\section{Mapping the Project Networks}

Drawing on Law and Callon's (1992) methodology, we can delineate the PEMS project into a set of key decision points which had consequences for both local and global networks, as summarised in Table 2 (note this includes the project pre-history as the first element).

Table 2. Project Decisions and Local/Global Network Consequences

\begin{tabular}{|c|c|c|c|}
\hline NO. & DECISION & LOCAL CONSEQUENCES & $\begin{array}{c}\text { GLOBAL } \\
\text { CONSEQUENCES }\end{array}$ \\
\hline$A$ & To develop CIGAS/TAS & $\begin{array}{l}\text { System development, training } \\
\text { and use }\end{array}$ & Prior resourcing \\
\hline $\boldsymbol{B}$ & $\begin{array}{l}\text { To modernise MoF through } \\
\text { technology-led change }\end{array}$ & - & $\begin{array}{l}\text { Project resourcing: ADB } \\
\text { grants funds, MoF to } \\
\text { provide counterpart funding } \\
\text { and support }\end{array}$ \\
\hline$C$ & $\begin{array}{l}\text { To appoint international } \\
\text { consultants }\end{array}$ & Articulate design policy & $\begin{array}{l}\text { Seek global 'best practice' } \\
\text { solutions }\end{array}$ \\
\hline$D$ & $\begin{array}{l}\text { To reject initial project } \\
\text { strategy }\end{array}$ & $\begin{array}{l}\text { Block consultants' } \\
\text { recommendations }\end{array}$ & $\begin{array}{l}\text { Reports of problems to } \\
\text { ADB by MoF }\end{array}$ \\
\hline $\boldsymbol{E}$ & $\begin{array}{l}\text { To reject and redesign whole } \\
\text { project }\end{array}$ & Crisis and disengagement & Crisis and visit meetings \\
\hline $\boldsymbol{F}$ & $\begin{array}{l}\text { To improve processes and } \\
\text { systems progressively }\end{array}$ & $\begin{array}{l}\text { Develop LogFrame; re- } \\
\text { engage with process }\end{array}$ & $\begin{array}{l}\text { Develop LogFrame; } \\
\text { reassign resources }\end{array}$ \\
\hline $\boldsymbol{G}$ & $\begin{array}{l}\text { To develop particular project } \\
\text { outputs, and publicise }\end{array}$ & $\begin{array}{l}\text { Develop system and } \\
\text { maintenance facility using } \\
\text { local resource }\end{array}$ & $\begin{array}{l}\text { Visible symbols of project } \\
\text { success }\end{array}$ \\
\hline
\end{tabular}

Building on this framework and using Law and Callon's (1992) network analysis model, we can now map out the changing nature of the local and the global network involved with the PEMS project. It would be appropriate to start our analysis just before PEMS, where a strong local network of potential actors existed with a commitment to CIGAS/TAS: not just the in-house developers and the trainers, but also those to whom the system had been rolled out, and the system itself given that ANT encompasses both human and non-human actors. This project had been funded and supported by financial and political resources from the ADB, but had rather taken on a 'life of its own' during the latter stages as the local network grew in strength. We 
therefore place this as point (A) on the chart shown in Figure 2, which summarises the PEMS project.

Just after this moment, the global network that had resourced CIGAS/TAS was reconstructed when the decision was taken by senior Ministry staff in collaboration with the Asian Development Bank to agree the new project transforming the Ministry through technology-led change (B). PEMS was designed and the first elements of a local network were brought into play for actual implementation: the team of international consultants (C).

They then sought - through a series of meetings and workshops - to mobilise other local actors who would form the basis for project implementation; including all those who had formed a well-mobilised network at point (A). But their efforts were not successful. CIGAS/TAS - the non-human actor - was explicitly excluded from the network because it would be replaced by a new system. Those allied to CIGAS/TAS and those whose salary incentives had been spent on the consultants' office could not be mobilised. Other senior MoF officials who were to drive and oversee implementation, self-excluded; in part due to the elections. The project thus moved from a situation $(\mathrm{C})$ of one mobilised group and others potentially mobilisable; to a situation (D) of one mobilised group and other actors un-mobilised.

Withdrawal of support from the MoF leadership within the global network ensued as they lost faith in the strategy their resources were providing for, and this rapidly led to a similar withdrawal of attachment of the ADB and their resources, leading to a project crisis (E). The ADB delegation was able to fairly quickly reconstruct the networks; first gaining buy-in from the highest levels of the Ministry by listening, redesigning, cajoling, threatening. And similar tactics then worked on the would-be implementers within the local network: the now-localised consultants, staff in the three focal Ministry departments, and the existing systems such as CIGAS/TAS.

Given what had come before, we can see this point (F) still as somewhat tentative in terms of the strength of the networks, with commitments being contingent. But as new artefacts were delivered and themselves joined the local network, those commitments gathered pace. This all culminated $(\mathrm{G})$ in end-of-project conferences 
that drew in new potential global network resourcers (such as the Minister of Finance and media and IPFDA), and local network implementers (such as individual members of IPFDA). These might also form the basis for local/global networks committed to further reform.

Figure 2. Local/Global Network Analysis of Sri Lanka Development Project

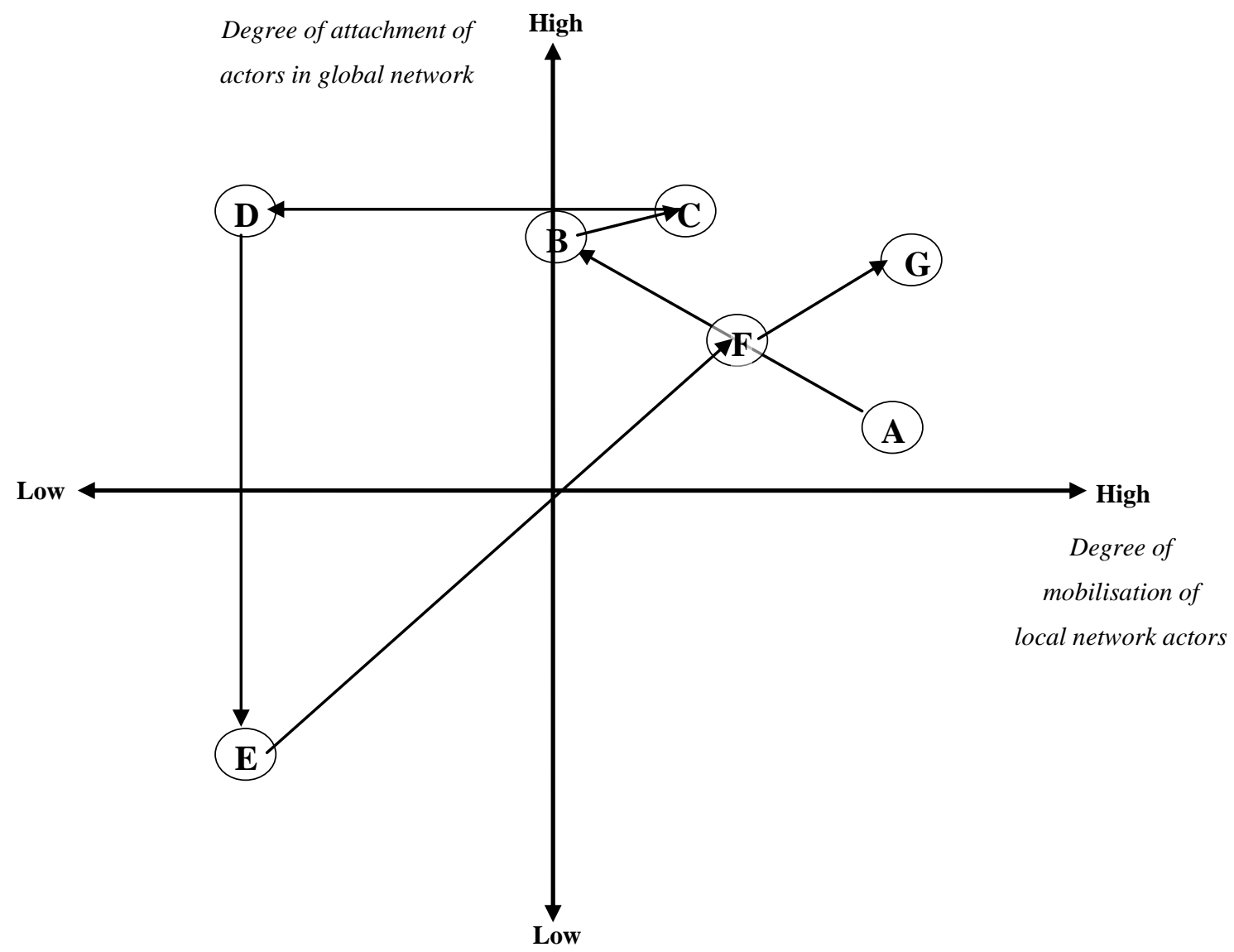




\section{Networks and Project Implementation}

On this foundation, we can compare the trajectory of the networks with the performance of this development project, as shown in Table 3, mapping the changing position of the network actors against the evolving shape of the project. Project implementation can be seen to have evolved in a contingent manner as a direct result of the inter-play of the various actors. We can describe the project as being of variable geometry that changed its shape over time as the states of design and implementation were influenced by the actors enrolled in the local and global networks.

The network analysis model does, therefore, seem to help in understanding the nature of project implementation and performance. The project was initially moving towards successful implementation. A global network of coinciding interests had been mobilised around an agreed project design. This global network created a space for action and provided a set of resources: not just money but also the more political resources of support and legitimacy for this particular approach to public sector reform. The negotiation space provided by this initial definition of the project goals gave privacy to the consultants, freedom from interference, autonomy and control over their work in preparing a strategy document in line with their expectations of what the global network required.

Had an effective local network been created by enrolling other actors then it could have generated a range of intermediaries to be passed back to the global network in return for resourcing - a more specific design of the new PEMS followed by project implementation deliverables. However, the ambitious initial strategy failed to establish itself as an obligatory point of passage. Design consensus had not been achieved. The 'international best practice' design was not seen by potential local network members - the very people who would have to implement it - as the means by which they could achieve their goals. 
Table 3. Project Implementation as a Function of Local/Global Networks and

\section{Inter-Relations}

\begin{tabular}{|c|c|c|c|}
\hline $\begin{array}{c}\text { PROJECT } \\
\text { IMPLEMENTATION } \\
\text { STAGE }\end{array}$ & $\begin{array}{c}\text { ENROLLED NETWORK } \\
\text { ACTORS }\end{array}$ & $\begin{array}{l}\text { NON-ENROLLED } \\
\text { NETWORK ACTORS }\end{array}$ & $\begin{array}{l}\text { NETWORK INTER- } \\
\text { RELATIONS }\end{array}$ \\
\hline $\begin{array}{l}\text { Initial Proposal and } \\
\text { Consultant Strategy } \\
(\mathrm{B} / \mathrm{C})\end{array}$ & $\begin{array}{l}\text { Global Network: } \\
\text { - MoF leadership focused } \\
\text { on organisational } \\
\text { transformation } \\
\text { - ADB focused on IT- } \\
\text { enabled public sector } \\
\text { reform } \\
\text { Local Network: } \\
\text { - International consultants } \\
\text { focused on delivery of } \\
\text { international 'best practice' } \\
\text { solution }\end{array}$ & $\begin{array}{l}\text { Potential Local Network } \\
\text { [blocked]: } \\
\text { - MoF State Accounts } \\
\text { Department concerned } \\
\text { about loss of } \\
\text { CIGAS/TAS progress } \\
\text { and high recurrent costs } \\
\text { - Other MoF departments } \\
\text { and line ministries } \\
\text { unhappy about costs, } \\
\text { benefits and procedural } \\
\text { changes }\end{array}$ & $\begin{array}{l}\text { - Project not } \\
\text { accepted as } \\
\text { obligatory point of } \\
\text { passage } \\
\text { - Lack of } \\
\text { intermediaries } \\
\text { between global and } \\
\text { potential local } \\
\text { network actors } \\
\text { - Non-enrolled } \\
\text { counter-interests } \\
\text { blocked by space } \\
\text { created by global } \\
\text { network }\end{array}$ \\
\hline $\begin{array}{l}\text { Initial Proposal Crisis } \\
\text { and Failure (D/E) }\end{array}$ & $\begin{array}{l}\text { Global Network: } \\
\text { - MoF leadership and } \\
\text { visiting ADB team accept } \\
\text { non-viability of initial } \\
\text { proposal } \\
\text { Local Network: } \\
\text { - MoF departments and line } \\
\text { ministries focus on failure } \\
\text { of initial proposal }\end{array}$ & $\begin{array}{l}\text { Potential Local Network } \\
\text { [blocked]: } \\
\text { - International } \\
\text { consultants still focused } \\
\text { on initial solution }\end{array}$ & $\begin{array}{l}\text { - Space created by } \\
\text { global network } \\
\text { blocked by non- } \\
\text { enrolled counter- } \\
\text { interests } \\
\text { - Initial proposal } \\
\text { failure and new } \\
\text { project direction } \\
\text { largely accepted as } \\
\text { OPP } \\
\text { - LogFrame } \\
\text { document as key } \\
\text { intermediary at end }\end{array}$ \\
\hline $\begin{array}{l}\text { New LogFrame and } \\
\text { Implementation (F/G) }\end{array}$ & $\begin{array}{l}\text { Global Network: } \\
\text { - MoF leadership focused } \\
\text { on local solutions and } \\
\text { visible technological } \\
\text { leadership } \\
\text { - ADB focused on longer- } \\
\text { term procedural change } \\
\text { Local Network: } \\
\text { - MoF departments and } \\
\text { IPFDA focused on } \\
\text { implementation of new } \\
\text { internal systems, and } \\
\text { changes to accounting } \\
\text { procedures }\end{array}$ & & $\begin{array}{l}\text { - LogFrame } \\
\text { document largely } \\
\text { accepted as OPP } \\
\text { - Local area network, } \\
\text { IBS and other } \\
\text { deliverables as key } \\
\text { intermediaries } \\
\text { - Network relations } \\
\text { routed via single } \\
\text { Project Director }\end{array}$ \\
\hline
\end{tabular}

The failure to mobilise an effective local network, the inability of the first project strategy document to establish itself as an obligatory point of passage between the networks, and the crisis situation that led the global network to then disintegrate - all these can be seen to underlie the initial trajectory of failure of this development project. But then the global network was able to re-form, populated by slightly different actors, and a new space for local network action was created. The 
boundaries of this new space - delineated in the Logical Framework document - were more attuned to the interests of the potential local network actors, mainly due to the apparently participative process by which that document had been created by the ADB. It thus established itself as an obligatory point of passage between the networks.

The central position of the Logical Framework was strengthened through the introduction of a single project director to act as the control and communication point between the global and local networks. This helped avoid the dangers of seepage; creating difficulties for any direct contacts between network members not routed through him. He was the one who had to handle the dialectic of the competing demands of the global and local networks for design-closure and detailed deliberation. His strategy was to manage the expectations of the global network with a series of interim deliverables (including progress reports and training workshop summaries) illustrating that the work specified in the Logical Framework was being done whilst facilitating the consultants undertaking the particular tasks (such as the IBS) that would meet the MoF's departmental requirements.

\section{Power, Politics and Project Implementation}

Actors in global networks might typically be expected to access sources of power unavailable to local network members and thus be able to impose their solution. Certainly that is what one would expect from a standard analysis of authoritative power in development projects (Lister, 2000; Pfeffer, 1992; Rondinelli, 1993). The $\mathrm{ADB}$ is a source of such power. It has legitimate power deriving from its formal, hierarchical authority. It has reward and coercive power from its ability to distribute or deny resources; notably funding. It also has technical power on the basis of its expertise in relation to implementation of financial management reform, and the application of new information and financial systems to achieve good governance and public administration reform goals. And yet, despite this sense in which it has 'power over' other stakeholders, its initially-formulated project approach failed. If the ability to get one's way in the face of opposition is at the heart of exercising power then this analysis shows that the ADB is - or at least was - not a powerful stakeholder. 
The success of the PEMS project crucially depended on the mobilisation of a local network of actors, to produce an agreed new financial system. But the ADB was unable to directly influence the shape of that system: it could not directly exercise power over the local network and its outputs. Why? Because it is not the static sense of 'power over' that matters - power is always in relation to something or someone else, and must be enacted. What matters is the 'power to' enact through others and this is a social power experienced in relationship with others.

For the ADB, its 'power to' was limited. The sheer heterogeneity of actors in the networks was one issue, pointing to what would have been a complex and costly enrolment process. The project designers failed to map out these complexities, something which is not so unusual within development projects: 'The typical [project] design describes the functions of [government] counterparts without the detailed analysis of the causes of shortcomings, process inefficiencies, power structures and communication gaps - or a clear description of how the counterparts are expected to function' (ADB, 2000: 27). The ADB also faced a resistant combination of actors both social and technical - that could not be enrolled by simple 'power over'. Initially, this was reflected in the combination of the State Accounts Department and its CIGAS/TAS application; later this grew by the enrolment of further social actors inside and outside the MoF.

The Logical Framework monitoring tool was used to good effect by the global network in the revised project to monitor the inputs, activities and outputs in a classical feedback control mechanism. But the ADB and the MoF leadership were only two of a number of actors in the expanding multiple networks as the PEMS project moved towards its conclusion and, when the networks are made up of such heterogeneous elements, the extent to which an actor can control these networks will always be problematic. 


\section{Conclusions}

The history of a development project from an actor-network perspective treats the world as a set of related bits and pieces in which there is no set social order; there are only endless attempts at ordering through the formation and stabilisation of networks. People, organisations, technological systems, documents were actors in the networks. They were afforded a voice and their attributes were acquired only in relation to these networks.

Law and Callon's analytical framework enabled a mapping of two main networks: a global one which provided resources in the broadest sense for a local one which actually undertook implementation of the project. The extent to which actors within each of those two networks could be cohesively mobilised was seen to help us understand why the project initially ran into problems and, later, why it was able to move to implement project deliverables. This also required an understanding of the connections between the two networks. Where this connection was limited, or ran through multiple conceptualisations of the project - as following production of the first strategy document - project implementation was challenged. Where this connection was a single agreed project design with a clearly-defined individual project director, project implementation proceeded relatively well.

In seeking to understand the mobilisation and connection of the local and global networks in this development project, we explored the politics of the project and sources of power. We found that static, resource-based notions of power - the simple 'power over' idea that those actors with authority or money or technical expertise would dominate - was neither supported by the project history nor conceptually appropriate. Instead, an actor-network view understands power in development projects as the 'power to' enact particular project design ideas or particular project implementation elements through other actors in a network.

ANT does therefore have something to offer in addressing the earlier-identified gaps in conceptualising and researching development projects. It encourages and facilitates the production of a thick description of project practice, encompassing a 
broad range of actors, and drawing out the dynamics of their actions and interrelations. It links variations in those dynamics to the trajectory of the development project. And it eschews formal, rational notions of project managerialism in favour of a perspective that recognises the central role of politics and power (conceived in a particular way) within development projects. ANT may, therefore, offer a bridge between development management and development politics.

Of course, within the context of a single case study and article, any claims must be proportionate. A truly thick description cannot be presented (and there are critiques that 'proper' ANT is only amenable to book-length exposition (Walsham, 1997)). Only one fraction of ANT thinking has been utilised, and the discussion of power should be seen as a starting point; one that would require separate analysis, for example to explore further the politics of translation. With those caveats remaining, we move to discuss the use of ANT in analysing development projects.

\section{Using ANT to Analyse Development Projects}

All development projects involve innovation, and thus there will always be struggle and conflict as old systems and allegiances give way to new practices, people and relationships. A strength of deploying ANT is that it enables the researcher to identify the actors and map interactions as they occur over time before relationships in the various networks congeal and became difficult to view. ANT is thus a systematic way of bringing out the 'net work' (Goguen, 1999).

Law and Callon's network analysis model is rarely used in ANT case studies and has never, as far as we know, been used to analyse a development project. This seems a little surprising given the insights it offers into project performance; moving beyond simplistic snapshot notions of 'success' or 'failure'. Instead it shows that any ongoing development project can never completely succeed or fail because its designs and its networks are continuously being re-formed. Not just the project overall but also its specific deliverables - what we could see in this case as its technical trajectory - is shown to be a function of the interaction of various heterogeneous elements as these were shaped and assimilated over time in two main networks. 
The local/global networks framework is of generic value in presenting a technique that is relatively accessible in its application, and yet which can deal with the complexities of a development project's implementation. There is a denial of both technological and social determinism and a focus instead on the combination and mutual constitution of the social and technical. The local/global networks framework offers a way of showing how the degree and form of mobilisation of the two networks and the way in which they are connected shape a project's trajectory. This insight provides a basis for analysis and proves to have practical value as well. However, the network analysis model is limited and a further analysis of power relations in networks needed to be employed in the case study to support the reader's understanding of the process of network mobilisation.

\section{Reflections on Development Project Practice}

From the case study analysis, management of development projects was seen to be an inherently political process. In contrast to traditional managerialist prescriptions, it was seen to mean focusing less on top-down control than on processes of persuasion; and less on analysing static sources of authority than on the dynamic ability to handle actor-networks. The focus from this perspective should be on the creation and maintenance of an effective and transparent global network to mobilise resources, on the creation and maintenance of an effective and accountable local network to implement the project, and on ensuring an agreed obligatory point of passage is shared by the two networks.

Planned control of those networks is unrealistic. But a means to address project issues as they arise during implementation, to take incremental action and to improvise as necessary is required. Project management needs to be 'a creative drifting process' (Ciborra, 1999), implying that the administrative point of passage must be through a culturally-embedded and committed individual.

Operating within the global network, international donor and development agencies cannot cause their development objectives to be achieved by act of stipulation. Instead, they must understand existing practices and how these can be re-appropriated in a network of other actors in a particular local environment. There are often 
requirements for development projects to be undertaken quickly and in conformity with claimed international best practice. But the analysis here shows how this may result in inadequate and insufficient assessments of the risks posed, punitive timelines, unrealistic demands and unmanageable complexities for the beneficiary organisation caused by the failure of the project designers and implementers to consider the due process required to introduce a new actor - that is, a development project innovation - into established networks.

\section{References}

Abouassi K. 2010. International development management through a Southern lens. Public Administration and Development 30(2): 116-123.

ADB. 1999. Technical Assistance Report TAR: SRI-32533 Proposed Technical Assistance to the Democratic Socialist Republic of Sri Lanka for Strengthening Public Expenditure Management Systems. ADB Publications Department: Manila, Philippines.

ADB. 2000. Special Evaluation Study of ADB-assisted PEM Projects. ADB Publications Department: Manila, Philippines.

ADB. 2001. Aide Memoire: Consultation on Strengthening Public Expenditure Management Systems TA 3301 (mimeo). Asian Development Bank: Manila, Philippines.

Bebbington AJ, Lewis D, Batterbury S, Olson E, Siddiqi MS. 2007. Of texts and practices: empowerment and organisational cultures in World Bank-funded rural development programmes. Journal of Development Studies 43(4): 597-621.

Bogason P, Toonen TAJ. 1998. Networks in public administration. Public Administration 76: 205-227.

Bond R, Hulme D. 1999. Process approaches to development: theory and Sri Lankan practice. World Development 27(8): 1339-1358. 
Callon M. 1986. Some elements of a sociology of translation: domestication of the scallops and the fishermen of St Brieuc Bay. In Power, Action and Belief: A New Sociology of Knowledge?, Law J (ed). Routledge \& Kegan Paul: London; 196-233.

Chandrasena S. 2003. Web-Based Access to User-Friendly Government Financial Statements in Sri Lanka, eTransparency Case Study no.10, eGovernment for Development Information Exchange. Available at: http://www.egov4dev.org/transparency/case/lankasad.shtml. Last accessed: September 4, 2012

Ciborra CU. 1999. A theory of information systems based on improvisation. In Rethinking Management Information Systems, Currie WL, Galliers B (eds). Oxford University Press: Oxford, UK; 136-155.

Diallo A, Thuillier D. 2005. The success of international development projects, trust and communication. International Journal of Project Management 23(3): 237-252.

Financial Times (Sri Lanka). 2003. Finance Ministry goes hi-tech: Choksy launches unique information network. Financial Times (Sri Lanka), 14 May.

Foucault M. 1984. The History of Sexuality, Volume 1: An Introduction. Penguin: Harmondsworth, UK.

Goguen J. 1999. Actor-network theory for information technology in developing nations. Panel presentation at international Workshop on Requirements Engineering, Buenos Aires, Argentina, 9 September.

Gow DD, Morss ER. 1988. The notorious nine: critical problems in project implementation. World Development 16(12): 1399-1418.

Ika LA, Diallo A, Thuillier D. 2009. Project management in the international development industry. International Journal of Managing Projects in Business 3(1): 61-93.

Ika LA, Lytvynov V. 2011. The "management-per-result" approach to international development project design. Project Management Journal 42(4): 87-104.

Khang DB, Moe TL. 2008. Success criteria and factors for international development projects. Project Management Journal 39(1): 72-84. 
Latour B. 1986. The powers of association. In Power, Action and Belief: A New Sociology of Knowledge?, Law J (ed). Routledge \& Kegan Paul: London; 264-280.

Latour B. 2005. Reassembling the Social: An Introduction to Actor-Network-Theory. Oxford University Press: Oxford, UK.

Law J. 1986. Power / knowledge and the dissolution of the sociology of knowledge. In Power, Action and Belief: A New Sociology of Knowledge?, Law J (ed). Routledge \& Kegan Paul: London; 1-19.

Law J. 1992. Notes on the theory of the actor-network: ordering, strategy, and heterogeneity. Systems Practice 5(4): 379-393.

Law J, Callon M. 1988. Engineering and sociology in a military aircraft project: a network analysis of technological change. Social Problems 35(3): 284-297.

Law J, Callon M. 1992. The life and death of an aircraft: a network analysis of technical change. In Shaping Technology/Building Society: Studies in Sociotechnical Change, Bijker WE, Law J (eds). MIT Press: Cambridge, MA; 21-52.

Leach M, Sumner A, Waldman L. 2008. Discourses, dynamics and disquiet: multiple knowledges in science, society and development Journal of International Development 20: 727-738.

Lewis D, et al. 2003. Practice, power and meaning: frameworks for studying organizational culture in multi-agency rural development projects. Journal of International Development 15: 541-557.

Lister S. 2000. Power in partnership? An analysis of an NGO's relationships with its partners. Journal of International Development 12(2): 227-239.

Long N. 1992. From paradigm lost to paradigm regained?. In The Battlefields of Knowledge: The Interlocking of Theory and Practice in Social Research and Development, Long N, Long A (eds). Routledge: London; 16-43. 
Mahanty S. 2002. Conservation and development interventions as networks: the case of the Indian Ecodevelopment Project, Karnataka. World Development 30(8): 1369-1386.

McCourt W, Gulrajani N. 2010. The future of development management. Public Administration and Development 30(2): 81-90.

Mosse D, Lewis D. 2006. Theoretical approaches to brokerage and translation in development. In Development Brokers and Translators, Lewis D, Mosse D (eds). Kumarian Press: Bloomfield, CT; 1-26.

Mowles C, Stacey R, Griffin D. 2008. What contribution can insights from the complexity sciences make to the theory and practice of development management?. Journal of International Development 20: 804-820.

Pfeffer J. 1992. Managing with Power: Politics and Influence in Organizations. Harvard Business School Press: Boston, MA.

PricewaterhouseCoopers. 2000. Strengthening Public Expenditure Management Systems Project Technical Proposal TA 3301-SRI (mimeo). Asian Development Bank: Manila, Philippines.

Rondinelli D. 1993. Development Projects as Policy Experiments, $2^{\text {nd }}$ edn. Routledge: London.

Rossi B. 2004. Revisiting Foucauldian approaches: power dynamics in development projects. Journal of Development Studies 40(6): 1-29.

Santiso C. 2001. Good governance and aid effectiveness. The Georgetown Public Policy Review 7(1): 1-22.

Stake RE. 2003. Case studies. In Handbook of Qualitative Research, $2^{\text {nd }}$ edn, Denzin NK, Lincoln YS (eds). Sage Publications: Thousand Oaks, CA; 134-164.

Struyk RJ. 2007. Factors in successful program implementation in Russia during the transition: pilot programs as a guide. Public Administration and Development 27(1): 63-83. 
Sumner A, Tribe M. 2008. International Development Studies: Theories and Methods in Research and Practice. Sage Publications: Los Angeles, CA.

Toner A, Franks T. 2006. Putting livelihoods thinking into practice: implications for development management. Public Administration and Development 26(1): 81-92.

van der Ploeg JD. 2006. Structure and agency. In The Elgar Companion to Development Studies, Clark DA (ed). Edward Elgar: Cheltenham, UK; 607-612.

Veldwisch GJ, Bolding A, Wester P. 2009. Sand in the engine: the travails of an irrigated rice scheme in Bwanje Valley, Malawi. Journal of Development Studies 45(2): 197-226.

Walsham G. 1997. Actor-network theory and IS research: current status and future prospects. In Information Systems and Qualitative Research, Lee AS, Liebenau J, DeGross JI (eds). Chapman \& Hall: London; 466-480.

Wholey J. 1979. Evaluation: Performance and Promise. The Urban Institute: Washington, DC.

Williams D, Young T. 1994. Governance, the World Bank and liberal theory. Political Studies 42(1): 84-100.

Yin R. 2003. Case Study Research: Design and Methods, $3^{\text {rd }}$ edn. Sage Publications: Thousand Oaks, CA. 